\title{
Optimize Fertilizer Use Management through Soil Health Assessment: Saves Money and the Environment
}

\author{
A. K. Singh*, M. L. Roy and A. K. Ghorai \\ Crop Production Division, ICAR-Central Research Institute for jute and Allied Fibres \\ (CRIJAF), Barrackpore, Kolkata-700120, West Bengal, India \\ *Corresponding author
}

\section{A B S T R A C T}

\begin{tabular}{|l|}
\hline Ke y w o r d s \\
$\begin{array}{l}\text { soil health;jute-rice } \\
\text { cropping system; } \\
\text { NPK ratio;fertilizer } \\
\text { economics }\end{array}$ \\
\hline Article Info \\
\hline $\begin{array}{l}\text { Accepted: } \\
\text { 14 May 2020 } \\
\text { Available Online: } \\
\text { 10 June 2020 }\end{array}$ \\
\hline
\end{tabular}

More fertilizer doesn't always mean a higher crop production, if there isn't the right mix of nutrients, water and soil health conditions. Soil Health Card (SHC) assessment provide soil nutrient status of land holding of each farmer and advise corrective dosage of major fertilizers, micronutrient and soil amendments to maintain soil health and obtain a better yield. Our aim to investigate a prototype of a soil health checklist that exemplifies the uses of right fertilizer mixture in jute-rice-potato, jute-rice-lentil and jute-rice-mustard cropping system which would be regarded by farmers as useful and acceptable for monitoring soil health and minimise the soil pollution.Soil samples were collected from 89 farmer's field of the study area and analysed for 10 soil health parameters based on farmer's fertilizer uses and knowledge of local natural resources to examine the total NPK uses/ratio for each cropping system. The study finds that the consumption ratio of nitrogen, phosphorous and potassium was 1.1:2.3:1 in jute-ricelentil/mustard and 1.2:2.9:1 in jute-rice-potato cropping systemas against recommended ratio of $4: 2: 1$. The trends in use of phosphorous and potassium show largely a steady path, whereas consumption of nitrogen shows a declining trend.

\section{Introduction}

Crops require right mix of three nutrients viz. nitrogen $(\mathrm{N})$, phosphorus $(\mathrm{P})$, and potassium (K) or NPK. N helps in plant growth and development, P not only accelerates blooming and the growth of roots but also helps plants to withstand stress, and $\mathrm{K}$ helps the process of photosynthesis and is essential to plant growth. Fertilizers contribute about 50\% of total yield increase for most of crops (Das and Mandal, 2015). But recently, declining or stagnation of major crop yields has been recorded due to cumulative effects of many soil-related constraints and climatic risks (Sangral, 2015 and Islam and Bhuiyan, 2016).

Imbalanced use of $\mathrm{N}, \mathrm{P}$ and $\mathrm{K}$ leads to the loss of fertility of the soil over a period of time, which affects efficiency of fertilizer use and crop productivity (Pimentel et al., 2006 and Rahman et al., 2012). The problem is more severe in intensively cropped regions where farmers use excessive nitrogen 
fertilizer to attain yield levels harvested earlier with less fertilizer (Dwivedi, 2017 and Singh et al., 2013). Excessive use of fertilizer can also harm the environment and human health through emissions of GHG (methane, nitrous oxides, $\mathrm{CO}_{2}$ ) and eutrophication caused by the deposits of nitrate and phosphorus in water resources (Bumb and Baanante, 1996).

Gangetic plain region of West Bengal (India) has made a remarkable progress in achieving self-sufficiency in food production due to substantial intensification of cropping system, use of high yield crop varieties, expansion of irrigated areas and increased application of chemical fertilizers. Chemical NPKfertilizers are added to the soil by farmers in very high proportions within a short time period which exceeds the soil assimilative capacity (Patra et al., 2016).

NPK consumption ratio increased to 8.2:3.2:1 in 2013-14 as against recommended ratio of 4:2:1(Dwivedi,2017). The situation was grimmer in major agricultural states like Punjab and Haryana where NPK ratios were as high as 31.4:8:1 and 27.7:6.1:1, respectively (GOI, 2016). Though it has improved to $6.1: 2.5: 1$ in $2017-18$, it does not necessarily imply that usage of NPK fertilizer in agriculture has come down (Vishandass, 2019).

Imbalanced use of fertilizer without soil testing is creating a hazardous health impact both to soil and human health. Poor soil health significantly affects small and marginal farmers who often lack the education or resources to make the best management decisions for their soils (Testen et al., 2018). It has been recommended by researchers from various disciplines of agriculture and environmental science that involving endusers in learning and decision making are important in managing natural resources
(Bruynand Abbey, 2003). In view of soil health monitoring, a group of farmers under United States Department of Agriculture (USDA) developed a soil health monitoring tool named Soil Health Card (SHC). It is simple and effective extension tool for soil health monitoring. To protect soil health and for sustainable agriculture, the Government of India also launched similar type of Soil Health Cards (SHC) Scheme in the year 2015. SHC provide soil nutrient status of land holding of each farmer and advise corrective dosage of major fertilizers, micronutrient and soil amendments to maintain soil health and obtain a better yield. This SHC carries crop wise recommendation of nutrients and fertilizer required for the individual farms. Participatory processes in developing soil health monitoring procedures can have significant educational value among farmers. With this background, the present study was undertaken to assess a prototype of a soil health checklist that exemplifies the uses of right fertilizer mixture in the locally adopted cropping system which would be regarded by farmers as useful and acceptable for monitoring soil health.

\section{Materials and Methods}

This study was conducted by the Central Research Institute for Jute and Allied Fibres (CRIJAF) during the year 2017-18, in jute growing villages of West Bengal (India). A survey was conducted with 89 randomly selected households in four villages (Table 1) of two districts of West Bengal. The survey includes collection of information on agriculture practices and available farm resources. Jute-rice was the dominant cropping system in all sites. The mean annual rainfall was in ranges of 1200 to $1400 \mathrm{~mm}$ with maximum average temperature $35.7{ }^{\circ} \mathrm{C}$ in May and minimum $12.1{ }^{\circ} \mathrm{C}$ in January. A large proportion of farmers are marginal and subsistence landholders (82\%). 


\section{Sampling and laboratory analysis}

Soil samples were collected during February 2018 from 89 farmer's field of the study area (Figure 1) before land preparation of jute cultivation from plough-depth maintaining the ideal soil sampling protocol (Gupta, 2000). Five samples were collected from each farmer's fields and analysed for soil reaction $(\mathrm{pH})$, electrical conductivity (EC), organic carbon (OC), available phosphorus (P), available potassium (K), available sulphur $(\mathrm{S})$, available zinc $(\mathrm{Zn})$, available iron $(\mathrm{Fe})$, available manganese (Mn) and available boron (B) in soil laboratory of CRIJAF, Barrackpore. Soil $\mathrm{pH}$ was determined with the help of a glass electrode $\mathrm{pH}$ meter in soilwater ratio of 1:2.5 (Jackson, 1962). To measure EC, 1:1 method was used (Smith and Doran, 1996). Organic carbon in soil sample was determined volumetrically by wet oxidation method (Walkley and Black, 1934). Available P, K, S, Zn, Fe, Mn and B were analysed using Pusa STFR meter (IARI, 2016).

\section{Soil health card preparation}

At present, soil health card includes 12 parameters viz., $\mathrm{pH}, \mathrm{EC}, \mathrm{OC}, \mathrm{N}, \mathrm{P}, \mathrm{K}, \mathrm{S}, \mathrm{Zn}$, $\mathrm{Fe}, \mathrm{Mn}, \mathrm{Cu}, \mathrm{Mo}$ and $\mathrm{B}$. In this study, ten soil health indicators were determined based on farmer's fertilizer uses and knowledge of local natural resources. Soil organic carbon was considered as an index of $\mathrm{N}$ availability for fertilizer recommendation.

Required dosages of neem coated urea, single super phosphate or di-ammonium phosphate and muriate of potash per hectare were suggested for four crops (rice, potato, lentil and mustard) as preferred by the farmer group along with required doses of organic manure (FYM), gypsum or lime and bio-fertilizer per hectare indicating achievable potential yield per hectare (Figure 2).

\section{Results and Discussion}

Soil health indicators used in this study revealed that mean soil $\mathrm{pH}(6.0-8.5)$ and EC $\left(<1.0 \mathrm{dSm}^{-1}\right)$ were within the acceptable range for optimum plant growth (Table 2). In some farmer's plot, both $\mathrm{pH}$ and $\mathrm{EC}$ were slightly higher. On village average, organic carbon content was at low level $(0.30-0.48 \%)$ and needs frequent organic manuring. Soil test levels of $\mathrm{P}_{2} \mathrm{O}_{5}$, sulphur and micronutrients were found adequate to achieve yield goals. $\mathrm{K}_{2} \mathrm{O}$ contents in surface soil were low $(<110$ $\mathrm{kg} \mathrm{ha}{ }^{-1}$ ) in three villages (except Panchkahaniya). Whereas in BelleShankarpur village, sulphur $(<10 \mathrm{ppm})$ and boron $(<0.2$ ppm) contents in surface soil were found deficient. Application of these plant nutrients through gypsum (140 kg ha ${ }^{-1}$ soil application) and borax ( $0.25 \%$ foliar spray) is essential for jute, mustard and rice crop. Low $\mathrm{K}_{2} \mathrm{O}$ in soil impairs grain/fruit quality and plants may be sensitive to disease infestation.

The study finds that the use of nitrogen, phosphorous and potassium (N: P: K ratio) did not follow the recommended consumption ratio of $4: 2: 1$ in the area. The average N:P:K ratio was 1.1:2.3:1 in jute-rice-lentil/mustard and 1.2:2.9:1 in jute-rice-potato cropping system (Figure 3). The trends in use of phosphorous and potassium show largely a steady path, whereas consumption of nitrogen shows a declining trend. Although the farmers heard about the on-going SHC scheme, they were quite ignorant about the scheme in details. They had little knowledge about soil sampling procedure and average area covered under soil testing. This also reflects lack of awareness among farmers about use of appropriate fertilizer use technology for enhancing or sustaining crop production. The farmers involved in this study can be characterised in a number of ways, e.g. by location, size of farm, farming practices and experience (Table 1). 
Table.1 Location of the study area in West Bengal, India

\begin{tabular}{|c|c|c|c|c|c|c|}
\hline \multirow[t]{2}{*}{ Village } & \multicolumn{2}{|c|}{$\begin{array}{l}\text { Village Location } \\
\text { (Decimal format) }\end{array}$} & \multirow[t]{2}{*}{$\begin{array}{l}\text { No. of } \\
\text { farmers }\end{array}$} & \multirow{2}{*}{$\begin{array}{c}\text { Operational } \\
\text { land } \\
\text { holdings } \\
\text { (ha) }\end{array}$} & \multirow{2}{*}{$\begin{array}{c}\text { Jute } \\
\text { area per } \\
\text { farmer } \\
\text { (ha) }\end{array}$} & \multirow{2}{*}{$\begin{array}{c}\text { Mean } \\
\text { farming } \\
\text { experience } \\
\text { (years) }\end{array}$} \\
\hline & Latitude & Longitude & & & & \\
\hline Galdaha & 22.7700 & 88.8866 & 37 & 0.52 & 0.36 & 18 \\
\hline Dwip Media & 22.6988 & 88.8616 & 19 & 0.87 & 0.72 & 19 \\
\hline BelleShankarpur & 22.8622 & 88.4547 & 9 & 0.64 & 0.44 & 20 \\
\hline Panchkahaniya & 22.9508 & 88.5863 & 24 & 0.72 & 0.52 & 16 \\
\hline
\end{tabular}

Note: Mean value of data for each group in the respective village

Table.2 Soil characteristics of study villages in West Bengal, India

\begin{tabular}{|c|c|c|c|c|c|c|c|c|}
\hline \multirow[t]{3}{*}{ Soil characteristics } & \multicolumn{8}{|c|}{ Village } \\
\hline & \multicolumn{2}{|c|}{$\begin{array}{l}\text { Galdaha } \\
(\mathrm{N}=37)\end{array}$} & \multicolumn{2}{|c|}{$\begin{array}{l}\text { Belle Shankarpur } \\
\qquad(\mathrm{N}=9)\end{array}$} & \multicolumn{2}{|c|}{$\begin{array}{l}\text { Dwip Media } \\
(\mathrm{N}=19)\end{array}$} & \multicolumn{2}{|c|}{$\begin{array}{c}\text { Panchkahaniya } \\
(\mathrm{N}=24)\end{array}$} \\
\hline & $\begin{array}{l}\text { Mean } \\
\text { (Range) }\end{array}$ & SD & $\begin{array}{c}\text { Mean } \\
\text { (Range) }\end{array}$ & SD & $\begin{array}{l}\text { Mean } \\
\text { (Range) }\end{array}$ & SD & $\begin{array}{l}\text { Mean } \\
\text { (Range) }\end{array}$ & $\mathrm{SD}$ \\
\hline pH & $\begin{array}{c}8.45 \\
(7.34-9.11)\end{array}$ & 0.43 & $\begin{array}{c}7.38 \\
(7.1-8.01)\end{array}$ & 0.29 & $\begin{array}{c}8.39 \\
(7.06-8.86)\end{array}$ & 0.40 & $\begin{array}{c}7.78 \\
(7.01-8.60)\end{array}$ & 0.47 \\
\hline $\operatorname{EC}\left(\mathrm{dsm}^{-1}\right)$ & $\begin{array}{c}0.54 \\
(0.15-1.03)\end{array}$ & 0.18 & $\begin{array}{c}0.37 \\
(0.22-0.56)\end{array}$ & 0.13 & $\begin{array}{c}0.62 \\
(0.38-1.40)\end{array}$ & 0.22 & $\begin{array}{c}0.41 \\
(0.18-0.56)\end{array}$ & 0.09 \\
\hline Org. C (\%) & $\begin{array}{c}0.48 \\
(0.21-0.87)\end{array}$ & 0.17 & $\begin{array}{c}0.33 \\
(0.24-0.44)\end{array}$ & 0.07 & $\begin{array}{c}0.40 \\
(0.23-0.66)\end{array}$ & 0.11 & $\begin{array}{c}0.30 \\
(0.12-0.46)\end{array}$ & 0.10 \\
\hline Avail. $P\left(\mathrm{~kg} \mathrm{ha}^{-1}\right)$ & $\begin{array}{c}54.21 \\
(13.7-105)\end{array}$ & 25.0 & $\begin{array}{c}33.52 \\
(5.20-67.8)\end{array}$ & 17.7 & $\begin{array}{c}46.81 \\
(9-138)\end{array}$ & 33.9 & $\begin{array}{c}32.51 \\
(8.7-92.6)\end{array}$ & 24.9 \\
\hline Avail. K (kg ha $\left.{ }^{-1}\right)$ & $\begin{array}{c}72.97 \\
(13.8-182)\end{array}$ & 42.9 & $\begin{array}{c}90.47 \\
(33.7-153)\end{array}$ & 42.5 & $\begin{array}{c}70.35 \\
(10.6-122)\end{array}$ & 30.6 & $\begin{array}{c}111.30 \\
(32.8-169)\end{array}$ & 37.1 \\
\hline Avail. S (mg kg $\left.{ }^{-1}\right)$ & $\begin{array}{c}10.21 \\
(0.13-30.1)\end{array}$ & 8.32 & $\begin{array}{c}3.53 \\
(1.95-7.46)\end{array}$ & 1.93 & $\begin{array}{c}20.72 \\
(17.4-28.7)\end{array}$ & 2.82 & $\begin{array}{c}2.85 \\
(0.50-6.08)\end{array}$ & 1.15 \\
\hline Avail. $\mathrm{Zn}\left(\mathrm{mg} \mathrm{kg}^{-1}\right)$ & $\begin{array}{c}10.03 \\
(3.9-21.9)\end{array}$ & 4.25 & $\begin{array}{c}2.97 \\
(1.21-5.21)\end{array}$ & 1.16 & $\begin{array}{c}5.65 \\
(0.30-19.2)\end{array}$ & 5.59 & $\begin{array}{c}7.71 \\
(1.20-16.8)\end{array}$ & 4.64 \\
\hline Avail. $\mathrm{Fe}\left(\mathrm{mg} \mathrm{kg}^{-1}\right)$ & $\begin{array}{c}41.35 \\
(6.01-92.33)\end{array}$ & 6.01 & $\begin{array}{c}7.26 \\
(4.30-12.5)\end{array}$ & 2.39 & $\begin{array}{c}19.77 \\
(2.88-103)\end{array}$ & 23.1 & $\begin{array}{c}19.65 \\
(2.70-45.1)\end{array}$ & 11.1 \\
\hline Avail. $M n\left(\mathrm{mg} \mathrm{kg}^{-1}\right)$ & $\begin{array}{c}18.24 \\
(9.16-35.48)\end{array}$ & 6.73 & $\begin{array}{c}1.93 \\
(1.10-2.90)\end{array}$ & 0.66 & $\begin{array}{c}12.06 \\
(2.72-18.84)\end{array}$ & 4.39 & $\begin{array}{c}4.11 \\
(2.27-8.08)\end{array}$ & 1.75 \\
\hline Avail. B (mg kg $\left.{ }^{-1}\right)$ & $\begin{array}{c}1.19 \\
(0.45-1.89)\end{array}$ & 0.33 & $\begin{array}{c}0.19 \\
(0.06-0.29)\end{array}$ & 0.07 & $\begin{array}{c}0.88 \\
(0.31-1.24)\end{array}$ & 0.24 & $\begin{array}{c}0.51 \\
(0.35-0.69)\end{array}$ & 0.08 \\
\hline
\end{tabular}


Table.3 Conventional fertilizer uses and SHC fertilizer recommendation in jute-ricepotato/lentil/mustard cropping system in West Bengal

\begin{tabular}{|c|c|c|c|c|c|c|c|c|c|c|c|c|}
\hline \multirow{2}{*}{$\begin{array}{l}\text { Village } \\
\text { Crop/Fertilizer use ((kg } \\
\left.\text { ha }^{-1}\right)\end{array}$} & \multicolumn{3}{|c|}{ Galdaha } & \multicolumn{3}{|c|}{ Belle Shankarpur } & \multicolumn{3}{|c|}{ Dwip Media } & \multicolumn{3}{|c|}{ Panchkahaniya } \\
\hline & Urea & SSP & MoP & Urea & SSP & MoP & Urea & SSP & MoP & Urea & SSP & $\mathrm{MoP}$ \\
\hline $\begin{array}{r}\text { Jute }\left(\mathbf{R Y}=35 \mathrm{qha}^{-1}\right) \\
\text { Conventional } \\
\text { SHC }\end{array}$ & $\begin{array}{l}100 \\
200\end{array}$ & $\begin{array}{l}350 \\
110\end{array}$ & $\begin{array}{c}120 \\
90\end{array}$ & $\begin{array}{l}125 \\
220\end{array}$ & $\begin{array}{l}240 \\
260\end{array}$ & $\begin{array}{c}150 \\
90\end{array}$ & $\begin{array}{l}160 \\
220\end{array}$ & $\begin{array}{l}190 \\
170\end{array}$ & $\begin{array}{l}100 \\
100\end{array}$ & $\begin{array}{l}170 \\
240\end{array}$ & $\begin{array}{l}210 \\
260\end{array}$ & $\begin{array}{c}120 \\
80\end{array}$ \\
\hline 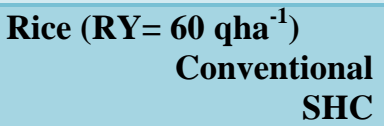 & $\begin{array}{l}105 \\
210\end{array}$ & $\begin{array}{l}375 \\
115\end{array}$ & $\begin{array}{l}125 \\
100\end{array}$ & $\begin{array}{l}130 \\
240\end{array}$ & $\begin{array}{l}250 \\
270\end{array}$ & $\begin{array}{l}160 \\
100\end{array}$ & $\begin{array}{l}170 \\
230\end{array}$ & $\begin{array}{l}195 \\
180\end{array}$ & $\begin{array}{l}105 \\
100\end{array}$ & $\begin{array}{l}180 \\
250\end{array}$ & $\begin{array}{l}225 \\
280\end{array}$ & $\begin{array}{c}135 \\
90\end{array}$ \\
\hline $\begin{array}{r}\text { Potato }\left(\mathrm{RY}=200 \mathrm{qha}^{-1}\right) \\
\text { Conventional } \\
\text { SHC }\end{array}$ & $\begin{array}{l}330 \\
430\end{array}$ & $\begin{array}{l}600 \\
350\end{array}$ & $\begin{array}{l}190 \\
285\end{array}$ & $\begin{array}{l}480 \\
470\end{array}$ & $\begin{array}{c}2400 \\
500\end{array}$ & $\begin{array}{l}675 \\
280\end{array}$ & $\begin{array}{c}- \\
470\end{array}$ & $\begin{array}{c}- \\
395\end{array}$ & $\begin{array}{c}- \\
285\end{array}$ & $\begin{array}{l}330 \\
490\end{array}$ & $\begin{array}{c}1800 \\
490\end{array}$ & $\begin{array}{l}480 \\
245\end{array}$ \\
\hline $\begin{array}{r}\text { Lentil }\left(\mathrm{RY}=\mathbf{8} \mathrm{qha}^{-1}\right) \\
\text { Conventional } \\
\text { SHC }\end{array}$ & $\begin{array}{l}40 \\
80\end{array}$ & $\begin{array}{l}225 \\
170\end{array}$ & $\begin{array}{c}75 \\
145\end{array}$ & $\begin{array}{c}110 \\
90\end{array}$ & $\begin{array}{l}190 \\
390\end{array}$ & $\begin{array}{c}45 \\
140\end{array}$ & $\begin{array}{c}- \\
90\end{array}$ & $\begin{array}{c}- \\
250\end{array}$ & $\begin{array}{c}- \\
140\end{array}$ & $\begin{array}{c}50 \\
100\end{array}$ & $\begin{array}{l}375 \\
410\end{array}$ & $\begin{array}{c}75 \\
120\end{array}$ \\
\hline $\begin{array}{r}\text { Mustard (RY=11 qha-1) } \\
\text { Conventional } \\
\text { SHC }\end{array}$ & $\begin{array}{l}150 \\
155\end{array}$ & $\begin{array}{c}300 \\
90\end{array}$ & $\begin{array}{l}75 \\
80\end{array}$ & $\begin{array}{l}110 \\
170\end{array}$ & $\begin{array}{l}180 \\
200\end{array}$ & $\begin{array}{l}45 \\
75\end{array}$ & $\begin{array}{c}90 \\
170\end{array}$ & $\begin{array}{l}270 \\
125\end{array}$ & $\begin{array}{l}105 \\
75\end{array}$ & $\begin{array}{l}270 \\
190\end{array}$ & $\begin{array}{l}330 \\
210\end{array}$ & $\begin{array}{l}90 \\
65\end{array}$ \\
\hline $\begin{array}{l}\text { Total Fertilizer use per } \\
\text { (in cropping system) }\end{array}$ & & & & & & & & & & & & \\
\hline $\begin{array}{l}\text { Jute-rice-potato } \\
\text { Conventional } \\
\text { SHC }\end{array}$ & $\begin{array}{l}575 \\
840\end{array}$ & $\begin{array}{c}1325 \\
575\end{array}$ & $\begin{array}{l}435 \\
475\end{array}$ & $\begin{array}{l}560 \\
930\end{array}$ & $\begin{array}{l}1690 \\
1030\end{array}$ & $\begin{array}{l}630 \\
470\end{array}$ & $\begin{array}{c}- \\
910\end{array}$ & - & $\begin{array}{c}- \\
485\end{array}$ & $\begin{array}{l}680 \\
980\end{array}$ & $\begin{array}{l}2235 \\
1030\end{array}$ & $\begin{array}{l}735 \\
415\end{array}$ \\
\hline $\begin{array}{l}\text { Jute-rice-lentil } \\
\text { Conventional } \\
\text { SHC }\end{array}$ & $\begin{array}{l}235 \\
490\end{array}$ & $\begin{array}{l}950 \\
420\end{array}$ & $\begin{array}{l}310 \\
335\end{array}$ & $\begin{array}{l}365 \\
550\end{array}$ & $\begin{array}{l}670 \\
920\end{array}$ & $\begin{array}{l}355 \\
330\end{array}$ & $\begin{array}{c}- \\
540\end{array}$ & $\begin{array}{c}- \\
600\end{array}$ & $\begin{array}{c}- \\
340\end{array}$ & $\begin{array}{l}400 \\
590\end{array}$ & $\begin{array}{l}810 \\
950\end{array}$ & $\begin{array}{l}330 \\
290\end{array}$ \\
\hline $\begin{array}{r}\text { Jute-rice-mustard } \\
\text { Conventional } \\
\text { SHC }\end{array}$ & $\begin{array}{l}360 \\
565\end{array}$ & $\begin{array}{c}1025 \\
315\end{array}$ & $\begin{array}{l}325 \\
280\end{array}$ & $\begin{array}{l}365 \\
630\end{array}$ & $\begin{array}{l}670 \\
730\end{array}$ & $\begin{array}{l}355 \\
265\end{array}$ & $\begin{array}{l}420 \\
620\end{array}$ & $\begin{array}{l}655 \\
475\end{array}$ & $\begin{array}{l}310 \\
275\end{array}$ & $\begin{array}{l}620 \\
680\end{array}$ & $\begin{array}{l}765 \\
750\end{array}$ & $\begin{array}{l}345 \\
235\end{array}$ \\
\hline
\end{tabular}

RY: Reference yield; SHC: Soil Health Card (soil test based fertilizer requirement); SSP: Single Super Phosphate;MoP: Muriate of Potash

Table.4 Total fertilizer uses (Conventional \& SHC) in jute-rice-potato/lentil/mustard cropping system

\begin{tabular}{|c|c|c|c|c|c|c|c|}
\hline \multirow[t]{2}{*}{ Cropping system } & \multicolumn{3}{|c|}{ NPK use $\left(\mathrm{kgha}^{-1} \mathrm{yr}^{-1}\right)$} & \multirow{2}{*}{$\begin{array}{c}\text { Total } \\
\text { NPK } \\
\text { (per year) }\end{array}$} & \multicolumn{3}{|c|}{ NPK ratio } \\
\hline & $\mathrm{N}$ & $\mathrm{P}$ & $\mathrm{K}$ & & $\mathrm{N}$ & $\mathrm{P}$ & $\mathrm{K}$ \\
\hline \multicolumn{8}{|l|}{ Conventional } \\
\hline Jute-rice-potato & 605 & 1750 & 600 & 2955 & 1.01 & 2.92 & 1.00 \\
\hline Jute-rice-lentil & 333 & 810 & 332 & 1475 & 1.00 & 2.44 & 1.00 \\
\hline Jute-rice-mustard & 441 & 779 & 334 & 1554 & 1.32 & 2.33 & 1.00 \\
\hline \multicolumn{8}{|l|}{ SHC recommended } \\
\hline Jute-rice-potato & 915 & 845 & 461 & 2221 & 1.98 & 1.83 & 1.00 \\
\hline Jute-rice-lentil & 543 & 723 & 324 & 1589 & 1.68 & 2.23 & 1.00 \\
\hline Jute-rice-mustard & 624 & 568 & 264 & 1455 & 2.36 & 2.15 & 1.00 \\
\hline
\end{tabular}




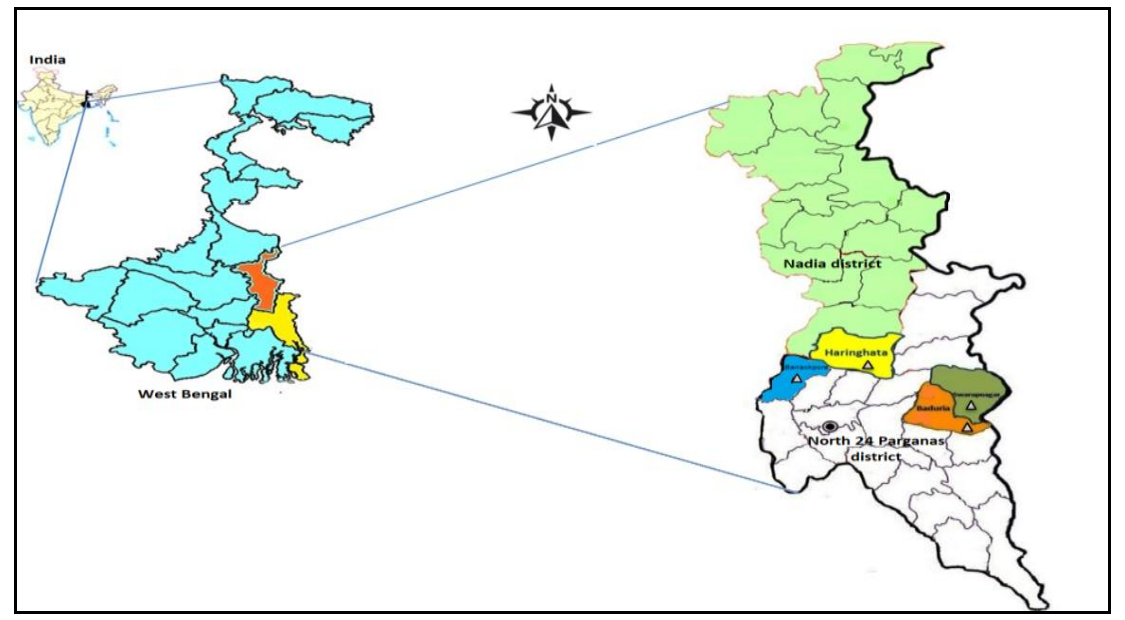

Figure.1 Location of study area for soil health study

ICAR-Central Research Institute
for Jute and Allied Fibres
Government of India

Figure.2 Soil Health Card provided to each farmer

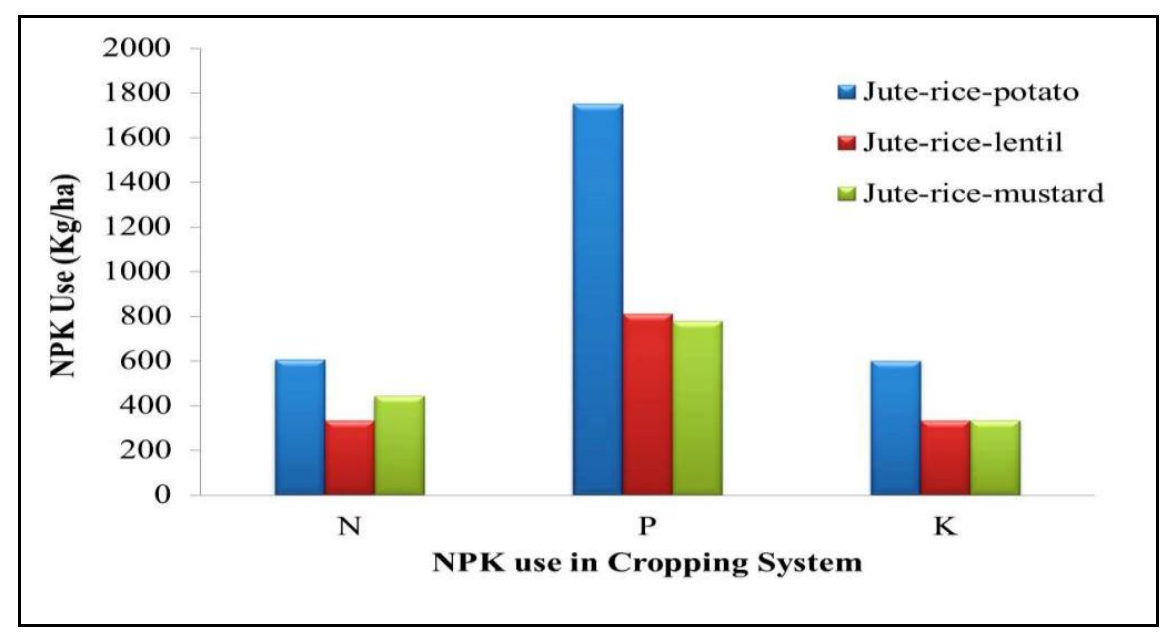

Figure 3.NPK fertilizer use in jute-rice-lentil/mustard/potato cropping system in West Bengal (India) 
Major cropping pattern followed in the study area were jute-rice-mustard/potato/lentil except in Dwip Media village where jutemustard-potato or lentil is not followed due to lowland and heavy soil texture. Jute and paddy (kharif) were grown as rainfed crop. Irrigation was applied only at the time of seed sowing of jute and transplanting of rice seedling.

The average productivity of paddy is $3450 \mathrm{~kg}$ $\mathrm{ha}^{-1}$, lentil $725 \mathrm{~kg} \mathrm{ha}^{-1}$, mustard $910 \mathrm{~kg} \mathrm{ha}^{-1}$ and potato $200 \mathrm{q} \mathrm{ha}^{-1}$. The farmers of the study area were not aware of judicious fertilizer management through use of SHC and therefore, they did not experience any reduction in consumption of chemical fertilizers. The farmers mainly applied complex NPK (10:26:26) fertilizer, Urea, Single Super Phosphate (SSP) and Muriate of Potash (MoP). Micronutrients were generally applied in vegetable crops only.

Farmer applies more amount of NPK complex fertilizer (10:26:26) as compared to Urea, SSP and MoP. Besides $\mathrm{NPK}_{10: 26: 26}$, they also add SSP and MoP in soil of each crop of jute-ricepotato/lentil/mustard cropping system. Urea was applied only as top dressing. Due to application of complex fertilizer $\left(\mathrm{NPK}_{10: 26: 26}\right)$ along with SSP as basal dose, phosphorus content has been increased about 2 to 3 times higher than the required quantity. Whereas, nitrogen dose has been reduced to 1.5 to 2 times than the recommended dose of juterice-potato/lentil/mustard cropping system. When $\mathrm{P}$ input from fertilizer exceeds $\mathrm{P}$ output in crop, $\mathrm{P}$ accumulates in soil over time (Kuo et al., 2005). If large amounts of $\mathrm{P}$ are supplied then luxury uptake of $\mathrm{P}$ may occur, which raises the ratios of $\mathrm{P}$ to $\mathrm{Fe}, \mathrm{Zn}$ and $\mathrm{B}$ (Murphy et al., 1981). Large P-inputs decrease soil $\mathrm{Zn}$ diffusion rates and enhances Fe immobilization in plant tissues (Haldar and Mandal, 1981).Inappropriate management of phosphate fertilizer can also be resulted in substantial waste of phosphorus which is a non-renewable inorganic chemical. Urea, the only fertilizer, is sold at uniform sale price and Phosphatic and Potassic fertilizers are sold at indicative maximum retail prices. While the prices of urea are fixed and government subsidy levels float, it is the other way round in case of $\mathrm{P}$ and $\mathrm{K}$. The current price of urea at ₹ 5,360 per tonne is low (due to subsidy) in relation to about ₹ 28,440 per tonne of DAP, ₹ 18,980 per tonne of MoP and ₹ 27,000 per tonne of NPK complex fertilizer $\left(\mathrm{NPK}_{10: 26: 26}\right)$. If farmer apply $\mathrm{NPK}_{10: 26: 26}$ only to meet the $100 \% \mathrm{P}$ and $\mathrm{K}$ and $40 \%$ of $\mathrm{N}$ requirement of each crop as basal dose, and Neem Coated Urea as top dressing to meet remaining amount of nitrogen than over use phosphorus can be reduced. In this situation, farmer has to purchase about $4 \mathrm{~kg}$ of $\mathrm{NPK}_{10: 26: 26}$ (₹ 110) and $3 \mathrm{~kg}$ of Neem Coated Urea (₹ 18) as top dressing to meet $1 \mathrm{~kg}$ of NPK requirement for each crop at lower cost (₹ 128) as compared to Urea (2 kg)+SSP (6 $\mathrm{kg})+\mathrm{MoP}(1.5 \mathrm{~kg})$ which cost about ₹ 600 . This combination saves about ₹ 472 per $\mathrm{kg}$ of NPK cost. To achieve the potential yield as per soil test value, amount of NPK fertilizer suggested (Table 3) in the given SHC along with deficient amount of sulphur and boron. As per crop requirement in the same cropping system and soil test level (SHC), the $\mathrm{N}$ ratio can be increased up to 2.36 times over existing fertilizer use practices (Table 4).

This study and its findings have direct implications for understanding the soil health card for improving soil fertility and crop productivity at the farm level. Soil indicators that assess each soil's ability to support crop production within its capabilities and site limitations can guide the farmers for selecting right fertilizer and its quantity as per their crops in each season. It is important to assess the adoption level of SHC and consequent benefits in soil fertility improvement, yield change and additional economic gains. 
Crop-wise recommendation of fertilizers provided in the SHC can help farmers to identify health related issues of soil and judiciously use of fertilizer. Judicious use of fertilizer also minimizes nutrient pollution and helps in building healthy soils. Much greater emphasis is needed on soil health monitoring for better fertilizer recommendation and its proper implementation by the farming community.

\section{Acknowledgement}

Authors of this study are thankful to the Director, ICAR-CRIJAF, Barrackpore for providing financial facilities and Crop Production Division, ICAR-CRIJAF for laboratory facilities in conducting the study.

\section{References}

Bumb,Balu L. and Baanante, Carlos A. 1996.Policies to promote environmentally sustainable fertilizer use and supply to 2020.2020 Brief 40, International Food Policy Research Institute, Washington DC.

Bruyn,Lobry de L.A. and Abbey, J.A. 2003. Characterisation of farmers' soil sense and the implications for onfarm monitoring of soils health.Australian Journal Experimental Agriculture43: 285-305.

Das, D.K. and Mandal,Mitali.2015. Advanced technology of fertilizer uses for crop production. In: Sinha,Shishir, Pant,K.K.and Bajpai,Shailendra (Ed.), Fertilizer Technology-I Synthesis,Studium Press, New Delhi.

Dwivedi, B.S.2017.Revamping soil testing service: a pre-requisite for effective implementation of Soil Health Card Scheme.Journal of Indian Society of Soil Science 65(S):62-71.

GOI. 2016.Impact of chemical fertilizers and pesticides on agriculture and allied sectors in the country.Standing Committee Report, Government of India, New Delhi.

Gupta, P.K. 2000.Methods in environmental analysis: water, soil and air. Agrobios Publication, Jodhpur, India.

Haldar,M. and Mandal, L.N. 1981.Effect of phosphorus and zinc on the growth and phosphorus, zinc, copper, iron, and manganese nutrition of rice.Plant Soil 59:415-425.

IARI.2016.Digital Soil Testing Mini Lab Technology.ICAR - IARI, Pusa, New Delhi.

Islam, S.M.D. andBhuiyan, M.A.H. 2016. Impact scenarios of shrimp farming in coastal region of Bangladesh: an approach of an ecological model for sustainable management. Aquaculture International 24(4):1163-1190.

Jackson, M.L. 1962.Soil chemical analysis. Prentice Hall Inc., Englewood Cliffs, New York.

Kuo S, Huang, B. and Bembenek, R. 2005.Effects of long-term phosphorus fertilization and winter cover cropping on soil phosphorus transformations in less weathered soil. Biology and Fertility of Soils 41:116-123.

Murphy, L.S., Ellis, R. and Adriano, D.C. 1981. Phosphorus-micronutrient interaction effects on crop production. Journal of Plant Nutrition 3: 597-613.

Patra, Suman, Mishra,Pulak,Mahapatra, S.C. and Mithun, S.K.2016.Modeling impacts of chemical fertilizer on agricultural production: a case study on Hoogly district, West Bengal, India.Modelling Earth Systems and Environment 2(4): 1-11.

Pimentel, D., Hepperly, P., Hanson, J., Douds, D. and Seidel, R. 2005.Environmental, energetic and economic comparisons of organic and conventional farming systems.Bioscience 55: 573-582. 
Rahman, M.A.T.M.T.,Aktar, Z., Mondal, M.K.and Ahmed, T. 2012.Environmental friendly agricultural practice in the southwestern coastal zone of Bangladesh to adapt with climate change.International Journal of Innovative Research Development 1(9):33-44.

Sangral, C. 2015.Changes in cropping pattern and crop diversification in Jammu and Kashmir.IOSR J Humanities and Social Science 20(4):7-9.

Singh, V.K.,Dwivedi, B.S., Buresh, R.J., Jat, M.L., Majumdar, K.,Gangwar, B, Govil, V. and Singh, S.K. 2013. Potassium fertilization in rice-wheat system across northern India: crop performance and soil nutrients. Agronomy Journal 105: 471-481.

Smith, J.L. and Doran, J.W. 1996. Measurement and use of $\mathrm{pH}$ and electrical conductivity for soil quality
analysis.Doran,J.W.and Jones, A.J. (Ed.),Methods for assessing soil quality, Special Publication ofSoil Science Society of America, No. 49, Madison.

Testen, Anna L., Mamiro,Delphina P., Nahson, Jackson, Amuri,Nyambilila A., Culman, Steven W.and Miller, Sally A. 2018. Farmer-focused tools to improve soil health monitoring on smallholder farms in the Morogoro region of Tanzania. Plant Health Progress 19:5663.

Vishandass, A. 2019.DBT of fertilizers subsidy: The last mile to walk.Indian Institute of Public Administration (CACP), New Delhi.

Walkley, A. and Black, I.A. 1934. An examination of the Degtjareff method for determining organic carbon in soils: effect of variations in digestion conditions and of inorganic soil constituents. Soil Science 63:251-263.

\section{How to cite this article:}

Singh. A. K., M. L. Roy and Ghorai. A. K. 2020. Optimize Fertilizer Use Management through Soil Health Assessment: Saves Money and the Environment. Int.J.Curr.Microbiol.App.Sci. 9(06): 322-330. doi: https://doi.org/10.20546/ijcmas.2020.906.042 